NASA/TM-2003-212730

\title{
Fuel Cells for Space Science Applications
}

Kenneth A. Burke

Glenn Research Center, Cleveland, Ohio 
Since its founding, NASA has been dedicated to the advancement of aeronautics and space science. The NASA Scientific and Technical Information (STI) Program Office plays a key part in helping NASA maintain this important role.

The NASA STI Program Office is operated by Langley Research Center, the Lead Center for NASA's scientific and technical information. The NASA STI Program Office provides access to the NASA STI Database, the largest collection of aeronautical and space science STI in the world. The Program Office is also NASA's institutional mechanism for disseminating the results of its research and development activities. These results are published by NASA in the NASA STI Report Series, which includes the following report types:

- $\quad$ TECHNICAL PUBLICATION. Reports of completed research or a major significant phase of research that present the results of NASA programs and include extensive data or theoretical analysis. Includes compilations of significant scientific and technical data and information deemed to be of continuing reference value. NASA's counterpart of peerreviewed formal professional papers but has less stringent limitations on manuscript length and extent of graphic presentations.

- TECHNICAL MEMORANDUM. Scientific and technical findings that are preliminary or of specialized interest, e.g., quick release reports, working papers, and bibliographies that contain minimal annotation. Does not contain extensive analysis.

- CONTRACTOR REPORT. Scientific and technical findings by NASA-sponsored contractors and grantees.
- CONFERENCE PUBLICATION. Collected papers from scientific and technical conferences, symposia, seminars, or other meetings sponsored or cosponsored by NASA.

- SPECIAL PUBLICATION. Scientific, technical, or historical information from NASA programs, projects, and missions, often concerned with subjects having substantial public interest.

- TECHNICAL TRANSLATION. Englishlanguage translations of foreign scientific and technical material pertinent to NASA's mission.

Specialized services that complement the STI Program Office's diverse offerings include creating custom thesauri, building customized databases, organizing and publishing research results ... even providing videos.

For more information about the NASA STI Program Office, see the following:

- Access the NASA STI Program Home Page at http://www.sti.nasa.gov

- E-mail your question via the Internet to help@sti.nasa.gov

- Fax your question to the NASA Access Help Desk at 301-621-0134

- Telephone the NASA Access Help Desk at 301-621-0390

- Write to:

NASA Access Help Desk

NASA Center for AeroSpace Information 7121 Standard Drive

Hanover, MD 21076 
NASA/TM-2003-212730

AIAA-2003-5938

\section{Fuel Cells for Space Science Applications}

Kenneth A. Burke

Glenn Research Center, Cleveland, Ohio

Prepared for the

First International Energy Conversion Engineering Conference

sponsored by the American Institute of Aeronautics and Astronautics

Portsmouth, Virginia, August 17-21, 2003

National Aeronautics and

Space Administration

Glenn Research Center 


\section{Acknowledgments}

The author wishes to thank the Office of Space Science Energy Storage Review Committee for the use of battery data presented at the September 26, 2002 review meeting held at the Goddard Space Flight Center.

Available from

NASA Center for Aerospace Information 7121 Standard Drive

Hanover, MD 21076
National Technical Information Service 5285 Port Royal Road Springfield, VA 22100

Available electronically at http:/ /gltrs.grc.nasa.gov 


\title{
Fuel Cells For Space Science Applications
}

\author{
Kenneth A. Burke \\ National Aeronautics and Space Administration \\ Glenn Research Center \\ Cleveland, Ohio 44135
}

\begin{abstract}
Fuel cell technology has been receiving more attention recently as a possible alternative to the internal combustion engine for our automobile. Improvements in fuel cell designs as well as improvements in lightweight high-pressure gas storage tank technology make fuel cell technology worth a look to see if fuel cells can play a more expanded role in space missions. This study looks at the specific weight density and specific volume density of potential fuel cell systems as an alternative to primary and secondary batteries that have traditionally been used for space missions. This preliminary study indicates that fuel cell systems have the potential for energy densities of $>500$ $\mathrm{W}-\mathrm{hr} / \mathrm{kg},>500 \mathrm{~W} / \mathrm{kg}$ and $>400 \mathrm{~W}-\mathrm{hr} / \mathrm{liter},>200 \mathrm{~W} / \mathrm{liter}$. This level of performance makes fuel cells attractive as high-power density, high-energy density sources for space science probes, planetary rovers and other payloads. The power requirements for these space missions are, in general, much lower than the power levels where fuel cells have been used in the past. Adaptation of fuel cells for space science missions will require "down-sizing" the fuel cell stack and making the fuel cell operate without significant amounts of ancillary equipment.
\end{abstract}

\section{INTRODUCTION}

NASA's fuel cell usage to date has consisted of Proton Exchange Membrane Fuel Cells (PEMFC) and Alkaline Fuel Cell (AFC) technology. Currently NASA is funding the development of only PEMFC and Direct Methanol Fuel Cell (DMFC) technology for space applications. No further development of AFC technology is envisioned. This paper will address only the PEMFC technology.

Both the PEMFC and AFC technologies that have flown in space have used hydrogen and oxygen reactants, which were delivered from external cryogenic tanks. NASA has used fuel cells instead of primary batteries for energy storage on almost all manned missions. Manned missions have required primary energy storage with long discharge times and generally higher power levels than unmanned missions. These requirements, as will be shown later in this paper, favor fuel cells rather than batteries because fuel cells are a lighter weight alternative. Space science missions, on the other hand, have generally involved shorter durations and lower power levels, which favor batteries rather than fuel cells. Consequently, NASA has used batteries of different types instead of fuel cells for energy storage on all unmanned space science missions.

The purpose of this study was to examine what "added value" fuel cells might provide (if any) to NASA as an alternative energy storage and power generation technology that would provide space science mission planners new or enhanced mission capabilities over existing and projected energy storage capabilities. Besides addressing "added value" niches, this study also was directed toward identifying fuel cell technology gaps that would need to be filled in order to meet the science mission requirements.

In order to meet the objectives of this study it was necessary to analyze the fuel cell system in terms of its weight, volume, power, efficiency and stored energy. These parameters were then compared to available and projected battery technologies to determine added value areas and what technology issues NASA would need to address to develop fuel cells to meet these areas.

\section{BACKGROUND}

The heart of a fuel cell is an electrochemical "cell" that combines a fuel and an oxidizing agent, and converts the chemical energy directly into electrical power. A "stack" of cells is usually employed in applications. For this paper, fuel cells will be described as either primary (not rechargeable) or secondary (rechargeable). Primary fuel cells for space use tanks of fuel and oxidant, which are gradually discharged and not replenished. Secondary fuel cells (also referred to as regenerative fuel cells) use hydrogen and oxygen and produce water and electrical power. An external power source is used to electrolyze the water to replenish the hydrogen and oxygen.

The amount of energy stored in the fuel and oxidant per unit mass is large compared to the energy stored in a typical battery. Unlike batteries, fuel cells generally do not store their fuel and oxidizer within the cell stack, but instead fuel and oxidizing agent are stored externally to the stack. Because of this characteristic, the energy capacity of a fuel cell power 
system is determined by the size of the fuel tanks, whereas the size of the fuel cell stack determines the power level. This situation is analogous to an automobile where the size of the fuel tank dictates how far you can drive, whereas the size of the automobile engine determines how fast you can drive. For space applications with long discharge times, the mass of the fuel cell and other process units is small compared to the mass of stored fuel, oxidant and tankage. This is the realm where fuel cells are most competitive on a energy per unit mass basis. For applications that run for a short time at moderate power levels, the mass of the fuel cell and other process units is significant, and reduces the competitiveness of fuel cells compared to batteries.

\section{NASA FUEL CELL USAGE HISTORY}

Launched in 1965, the Gemini V spacecraft was the first spacecraft to use fuel cells. These were PEM fuel cells developed specifically for the Gemini spacecraft by General Electric starting in 1962. Gemini 7,8,9,10,11 and 12 also used these fuel cells. The fuel cells were used as the main power source, with silver-zinc batteries used for peak loads. Cryogenic hydrogen and oxygen tanks stored the reactants for the fuel cells. The water produced by the fuel cells was used for drinking by the astronauts.

A Gemini spacecraft carried two hydrogen-oxygen fuel cell battery sections in its adapter/equipment section. Each battery section, shown in Figure 1, contained three stacks of fuel cells with plumbing. The stacks were connected in parallel and could be switched in and out of use individually. Each fuel cell stack, illustrated in Figure 2, had 32 individual cells connected in series and produced 23 to 26 volts. Maximum power output per battery section was about one kilowatt. The fuel cells operated at about $65^{\circ} \mathrm{C}[1],[2]$.

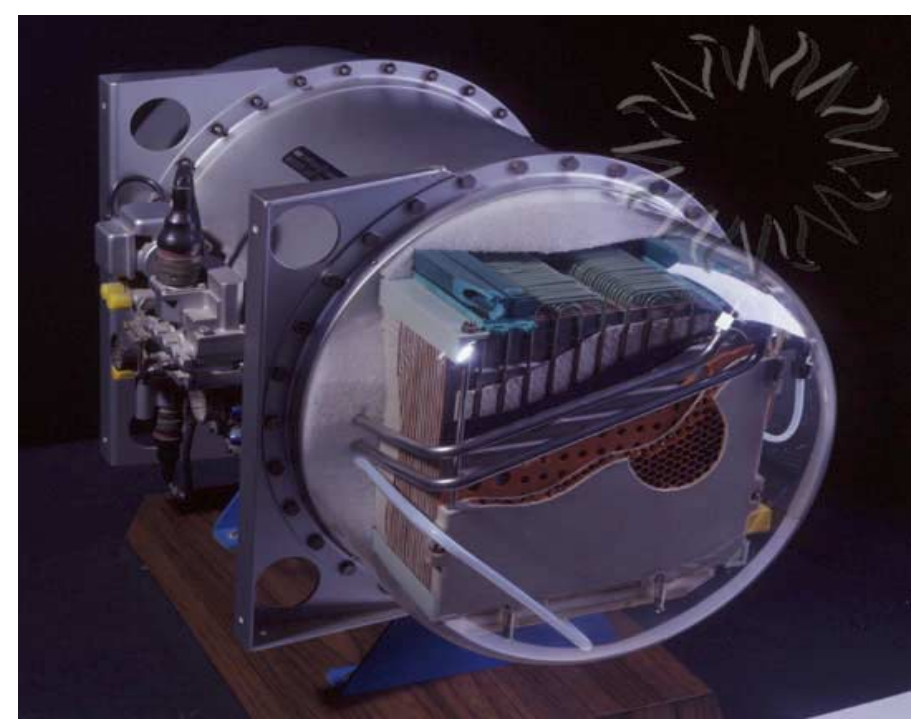

Figure 1 Gemini Battery Section [2]

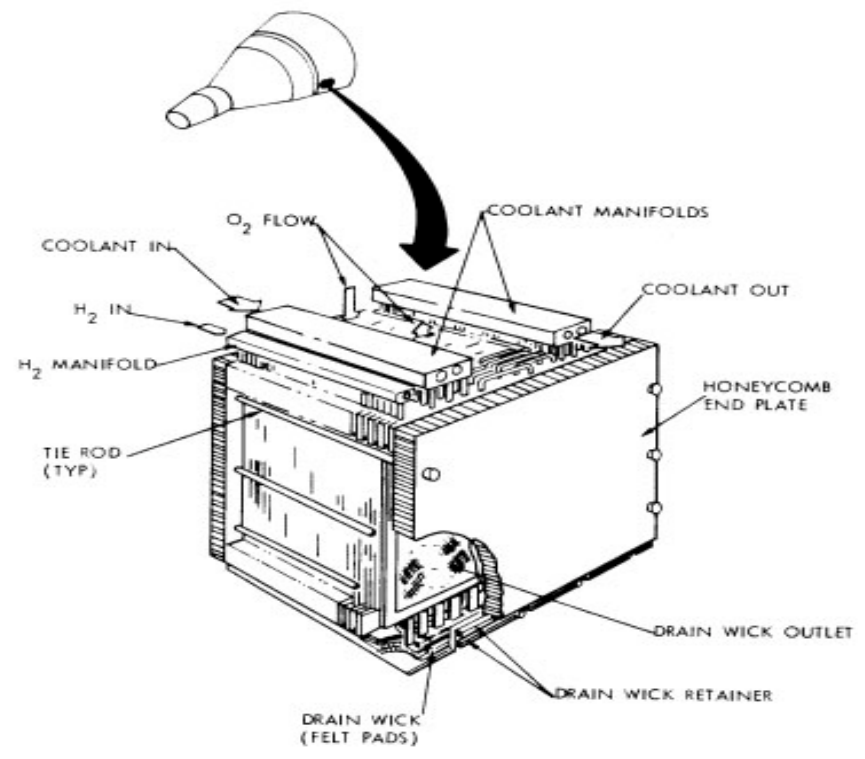

Figure 2 Gemini Fuel Cell Stack [2]

In 1963 Pratt and Whitney was selected to provide alkaline fuel cells for the Apollo Command and Service Module (CSM). The fuel cells provided both main and peaking power for the CSM. These fuel cells were used on all Apollo missions, the Apollo/Soyuz mission and Skylab.

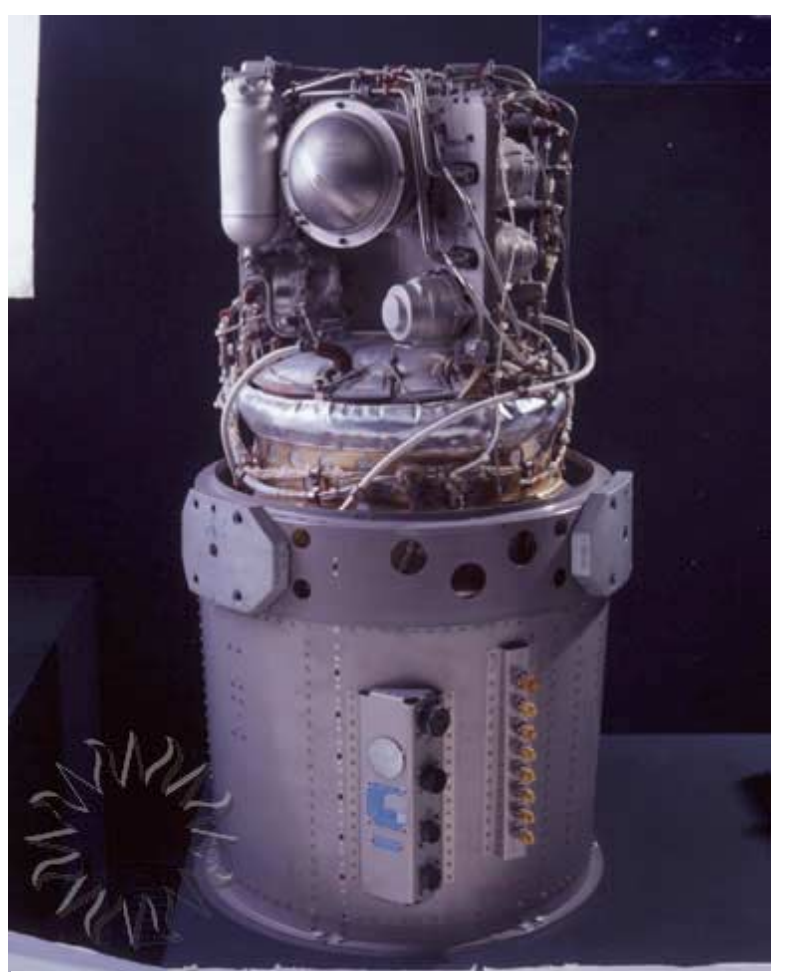

Figure 3 Apollo Fuel Cell [2] 
Apollo spacecraft carried three hydrogen-oxygen fuel cells in the CSM. The Apollo fuel cell is shown in Figure 3. Each unit contained 31 individual fuel cells connected in series and operated at 27 to 31 volts. Normal power output was 563 to 1420 watts, with a maximum of 2300 watts. The operating temperature was about $206{ }^{\circ} \mathrm{C}$. The mass of each unit was about $113 \mathrm{~kg}[2]$.

Electrical power for NASA's Space Shuttle Orbiter is provided by alkaline fuel cell power plants (shown in Figure 4). These were designed, developed, and built by UTC Fuel Cells. In the Orbiter, a complement of three $12 \mathrm{~kW}$ fuel cells produces all onboard electrical power; there are no backup batteries, and a single fuel cell is sufficient to insure safe vehicle return. In addition, the water produced by the electrochemical reaction is used for crew drinking and spacecraft cooling.

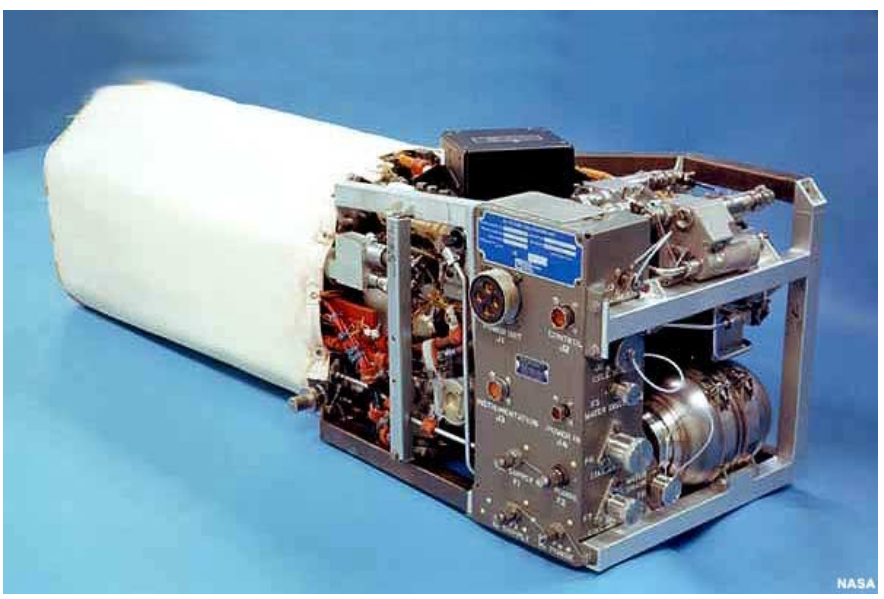

Figure 4 Space Shuttle Fuel Cell Power Plant [3]

Each Space Shuttle Orbiter fuel cell power plant is a selfcontained unit $14 \times 15 \times 45$ inches, weighing 118 kilograms. They are installed under the payload bay, just aft of the crew compartment. The power plants are fueled by hydrogen and oxygen from cryogenic tanks located nearby. Each fuel cell is capable of providing $12 \mathrm{~kW}$ continuously, and up to $16 \mathrm{~kW}$ for short periods [3]. Each power plant contains 96 individual cells of the alkaline $(\mathrm{KOH})$ electrolyte technology, which are connected to achieve a 28 volt output. The fuel cells nominal operating temperature is about $80{ }^{\circ} \mathrm{C}$. The cells are over $70 \%$ efficient; this high efficiency and light weight led NASA to select fuel cells to power the Space Shuttle Orbiter.

\section{ANALYSIS OF FUEL CELLS FOR SPACE SCIENCE APPLICATIONS}

The fuel cell data collected for this paper is not easily extrapolated to space science applications. There are several reasons for this. First, fuel cells have, up to this point, been used strictly for manned vehicle power generation as far as space applications go. These fuel cells are 10 to 100 times higher in power than has been typically used for science missions, and are 1000's of times higher in terms of total energy. This large difference in scale makes an assessment extremely difficult. Similarly, and not surprising, NASA's development of advanced fuel cell technology, has been directed toward high power, high energy manned applications, so assessing developing fuel cell technology for space science missions is likewise difficult. The fuel cell technology being developed for terrestrial applications is similarly being developed for high power automotive use or for large-scale power generation. Because of this situation, any assessment by direct evaluation of available or developing fuel cell technology was problematic.

To overcome the difficulty in directly assessing suitability of fuel cell technology for space science power and energy storage needs, an analysis was done to determine key metrics of the technology, that could place fuel cell technology on the energy storage "landscape", and provide a rationale for either including or excluding fuel cells as a space science energy storage technology. Fuel cells were considered for both primary and secondary energy storage applications, and compared against current and projected primary and secondary battery technology to see if fuel cells offered some advantages to space missions that batteries were not likely to meet. The primary and secondary fuel cells considered were PEMFC $\mathrm{H}_{2} / \mathrm{O}_{2}$ fuel cells shown conceptually in Figure 5. The main components of a fuel cell system are the reactants themselves, the reactant containment and the fuel cell stack. Although there are other components, the reactants, their containment vessels, and the fuel cell stack are by far the largest and heaviest components and as such account for a suitably large enough percentage of the total mass and volume for the purposes of this analysis.

\section{Primary Fuel Cells}

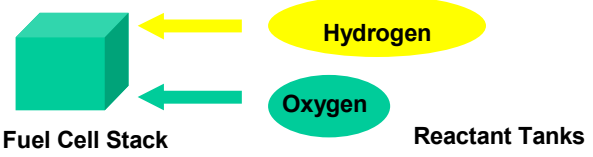

Secondary Fuel Cells

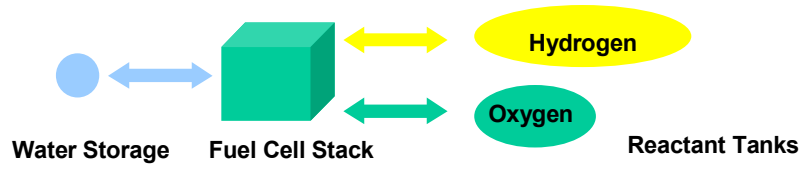

Figure 5 Primary and Secondary Fuel Cells

Primary fuel cells, like primary batteries, are energy storage devices that have $100 \%$ of their energy at the conclusion of the manufacturing process, and either through storage, leakage, or 
usage have that energy reduced until the primary energy storage device is considered "completely used". Primary fuel cells, unlike primary batteries, are capable of being "recharged" by simply refilling the reactant storage tanks, but during the space science mission this would not be done. The ability to "recharge" primary fuel cells could be advantageous during the ground verification program.

Secondary fuel cells (also known as regenerative fuel cells), like secondary batteries, are designed to be rechargeable.[4] The major difference between the primary and regenerative fuel cells is that for regenerative fuel cells, the water formed during the discharge reaction is stored and then electrolyzed back into hydrogen and oxygen during the charging part of the cycle. It is assumed here that the fuel cell stack itself acts as the electrolyzer. This kind of fuel cell sometimes goes by the name of "unitized" or "reversible" fuel cell. Although this type of fuel cell is a relatively recent technology development, this type of secondary fuel cell is more likely to fit within the smaller spacecraft used for space science missions.

One of the key comparison metrics for batteries is power density, measured in watts per kilogram. This is the power delivered by the battery divided by the mass of the battery. For fuel cells, this would be:

$\rho_{P}=\frac{P}{M_{F}+M_{B}}$

$$
\begin{aligned}
& \text { Where } \\
& \begin{aligned}
\rho_{\mathrm{P}} & =\text { Power Density, watts } / \mathrm{kg} \\
\mathrm{P} & =\text { Output Power, watts } \\
\mathrm{M}_{\mathrm{F}} & =\text { Mass of Fuel }\left(\mathrm{O}_{2}, \mathrm{H}_{2}, \text { and } \mathrm{H}_{2} \mathrm{O}\right), \mathrm{kg} \\
\mathrm{M}_{\mathrm{B}} & =\text { Mass of the Balance of Plant }(\mathrm{BOP}), \mathrm{kg}
\end{aligned}
\end{aligned}
$$

Rewriting the right-hand side of equation (1),

$\rho_{\mathrm{P}}=\frac{1}{\left(1 / \rho_{\mathrm{F}}\right)+\left(1 / \rho_{\mathrm{B}}\right)}$

Where

$\rho_{\mathrm{F}} \quad=$ Fuel Power Density, watts $/ \mathrm{kg}$

$\rho_{\mathrm{B}} \quad=$ Balance of Plant Power Density, watts $/ \mathrm{kg}$

The reason for writing equation (2) is that it is instructive to keep track of the individual contributions to the overall power density of each part of the fuel cell system. The fuel power density can itself be rewritten as:

$\rho_{\mathrm{F}}=\frac{\mathrm{E}}{\mathrm{t}_{\mathrm{d}} \mathrm{M}_{\mathrm{F}}}$

Where

$\mathrm{E}=$ Actual Energy Output, watt-hr

$\mathrm{t}_{\mathrm{d}} \quad=$ Discharge Time, $\mathrm{hr}$
Equation (3) can be rewritten as

$\rho_{\mathrm{F}}=\frac{\eta_{\mathrm{e}} \xi}{\mathrm{t}_{\mathrm{d}} \mathrm{M}_{\mathrm{F}}}$

Where

$$
\begin{aligned}
& \xi=\text { Theoretical Energy Output, watt-hr } \\
& \eta_{\mathrm{e}}=\text { Energy Conversion Efficiency, } \%
\end{aligned}
$$

The symbol, $\eta_{\mathrm{e}}$, combines both voltage and current efficiency into a single energy conversion efficiency. For secondary fuel cells, this would be the overall "roundtrip" energy efficiency. The theoretical energy output for the $\mathrm{H}_{2} / \mathrm{O}_{2}$ fuel cell reaction is 3661 watt-hr per $\mathrm{kg}$ of water formed (assuming 1.23 volts as the $100 \%$ voltage efficiency of the fuel cell). Since the mass of the fuel can be stated in terms of its water mass, the ratio of $\xi / \mathrm{M}_{\mathrm{F}}$ is 3661 watt-hr per $\mathrm{kg}$ of water formed. Rewriting equation (4),

$\rho_{\mathrm{F}}=\frac{3661 \eta_{\mathrm{e}}}{\mathrm{t}_{\mathrm{d}}}$

The balance of the fuel cell system is, for the purposes of this analysis, considered to consist of only the PEMFC stack and the high-pressure hydrogen and oxygen gas storage tanks. In the case of secondary fuel cells, a water storage tank is also included. Other ancillary flow elements such as pumps, filters, separators, etc., are not included. However, the masses of these elements are expected to be negligible for the kind of approximate analysis performed here. The balance of plant power density can then be written as:

$$
\rho_{\mathrm{B}}=\frac{P}{\mathrm{M}_{\mathrm{S}}+\mathrm{M}_{\mathrm{T}}}
$$

Where

$\mathrm{M}_{\mathrm{S}}=$ Mass of the PEMFC Stack, kg

$\mathrm{M}_{\mathrm{T}}=$ Mass of the Reactant Storage, $\mathrm{kg}$

Equation (6) can in turn be rewritten as:

$$
\rho_{\mathrm{B}}=\frac{1}{1 / \rho_{\mathrm{S}}+1 / \rho_{\mathrm{T}}}
$$

Where

$$
\begin{aligned}
& \rho_{\mathrm{S}}=\text { Stack Power Density, watt } / \mathrm{kg} \\
& \rho_{\mathrm{T}} \quad=\text { Tankage Power Density, watt } / \mathrm{kg}
\end{aligned}
$$

The PEMFC stack power density can be expressed as:

$$
\rho_{\mathrm{S}}=\mathrm{V}_{\mathrm{d}} \mathrm{I}_{\mathrm{d}} \mathrm{A}_{\mathrm{m}}
$$

$$
\begin{aligned}
& \text { Where } \\
& \mathrm{V}_{\mathrm{d}}
\end{aligned}
$$


$\mathrm{I}_{\mathrm{d}} \quad=$ Discharge Current Density, amp $/ \mathrm{m}^{2}$

$\mathrm{A}_{\mathrm{m}}=$ Active Area per Unit Mass, $\mathrm{m}^{2} / \mathrm{kg}$

The reactant storage power density can be written as:

$\rho_{\mathrm{T}}=\frac{\eta_{\mathrm{e}} \xi}{\mathrm{t}_{\mathrm{d}} \mathrm{M}_{\mathrm{T}}}$

For primary fuel cell systems the mass of the reactant storage is the mass of the oxygen and hydrogen tanks. The mass of these tanks can be estimated based on a figure of merit that relates the pressure, volume and dry mass of a state-of-the-art light-weight pressure vessel.

The figure-of-merit relationship is expressed as:

$\mu=\underline{\mathrm{P}}_{\mathrm{T}} \underline{\mathrm{V}}_{\mathrm{T}}$

Where

$\mu \quad=$ Tank Figure-of-Merit, atm-liter $/ \mathrm{kg}$

$\mathrm{P}_{\mathrm{T}} \quad=$ Max Tank Operating Pressure, atm

$\mathrm{V}_{\mathrm{T}}=$ Volume of tank, liter

Substituting the perfect gas law into equation (10),

$\mu=\frac{\left(\mathrm{n}_{\mathrm{H}}+\mathrm{n}_{\mathrm{O}}\right) \mathrm{RT}}{\mathrm{M}_{\mathrm{T}}}$

Where

$\mathrm{n}_{\mathrm{H}}=$ Moles of Hydrogen, gmole

$\mathrm{n}_{\mathrm{O}}=$ Moles of Oxygen, gmole

$\mathrm{R}=.082 \mathrm{~atm}$-liter- gmole $^{-1}-\mathrm{K}^{-1}$

$\mathrm{T} \quad=$ Gas Temperature, $\mathrm{K}$

Since the sum of oxygen moles and hydrogen moles is 1.5 times the number of water moles, equation (11) can be rewritten as:

$\mu=\frac{1.5 \mathrm{n}_{\mathrm{W}}}{\mathrm{M}_{\mathrm{T}}} \underline{\mathrm{RT}}$

Where

$\mathrm{n}_{\mathrm{W}}=$ Moles of Water, gmole

Solving equation (11) for $\mathrm{M}_{\mathrm{T}}$ and substituting this expression into equation (9),

$\rho_{\mathrm{T}}=\frac{\eta_{\mathrm{e}} \xi \mu}{1.5 \mathrm{t}_{\mathrm{d}} \mathrm{n}_{\mathrm{W}} \mathrm{RT}}$

The number of moles of water can be expressed as:
$\mathrm{n}_{\mathrm{W}}=\mathrm{M}_{\mathrm{F}} / .018$

When equation (14) is substituted into equation (13) and the ratio of $\xi / \mathrm{M}_{\mathrm{F}}$ is set equal to 3661 watt-hr $/ \mathrm{kg}$, the simplified result is:

$\rho_{\mathrm{T}}=\frac{3661 \eta_{\mathrm{e}} \mu}{83.3 \mathrm{t}_{\mathrm{d}} \mathrm{RT}}$

For secondary fuel cells the mass of the reactant storage is the mass of the oxygen and hydrogen tanks plus the mass of the water storage tank. The mass of the reactant storage for secondary fuel cells can be expressed as:

$\mathrm{M}_{\mathrm{T}}=\underline{1.5 \mathrm{n}_{\mathrm{w}} \underline{\mathrm{RT}}}+\mathrm{M}_{\mathrm{W}}$

Where

$\mathrm{M}_{\mathrm{W}}=$ Dry Mass of Water Storage Tank, kg

As was the case for the oxygen and hydrogen tanks, the mass of the water storage tank can be estimated using the same pressure vessel figure-of-merit.

$\mathrm{M}_{\mathrm{W}}=\underline{\mathrm{P}}_{\mathrm{T}} \underline{\mathrm{V}}_{\mathrm{w}}$

Where

$\mathrm{V}_{\mathrm{W}}=$ Water storage tank volume, liter

The volume of the water storage tank can be estimated from the water mass being stored. Since water is nearly incompressible,

$\mathrm{V}_{\mathrm{W}}=\frac{\mathrm{M}_{\mathrm{F}}}{\rho_{\mathrm{W}}}$

Where

$\rho_{\mathrm{W}}=1.0 \mathrm{~kg} / \mathrm{liter}$

Substituting equation (14), (17), and (18) into equation (16) and simplifying to obtain the mass of the reactant tankage for secondary fuel cells,

$\mathrm{M}_{\mathrm{T}}=\underline{83.3 \mathrm{M}_{\mathrm{F}}} \underline{\mathrm{RT}+\mathrm{P}_{\mathrm{T}}} \underline{\mathrm{M}}_{\mathrm{F}}$

$\mu$

Equation (19) can then be substituted into equation (9) to obtain an expression for the reactant storage power density for secondary fuel cells.

$\rho_{\mathrm{T}}=\frac{\eta_{\mathrm{e}} \xi \mu}{\mathrm{t}_{\mathrm{d}}\left(83.3 \mathrm{M}_{\mathrm{F}} \mathrm{RT}+\mathrm{P}_{\mathrm{T}} \mathrm{M}_{\mathrm{F}}\right)}$ 
When the ratio of $\xi / \mathrm{M}_{\mathrm{F}}$ is set equal to 3661 watt-hr/ $\mathrm{kg}$, the simplified expression for reactant power density for secondary fuel cells is:

$\rho_{\mathrm{T}}=\frac{3661 \eta_{\mathrm{e}} \mu}{\mathrm{t}_{\mathrm{d}}\left(83.3 \mathrm{RT}+\mathrm{P}_{\mathrm{T}}\right)}$

Substituting equations (8),(15), and (21) into equation (7) and developing expressions for the balance of plant power density for both primary and secondary fuel cells,

For primary fuel cells,

$\rho_{B}=\frac{3661 \eta_{\mathrm{e}} \mu \mathrm{t}_{\mathrm{d}}{ }_{\mathrm{d}}^{-1}}{3661 \eta_{\mathrm{e}} \mu\left(\mathrm{V}_{\mathrm{d}} \mathrm{I}_{\mathrm{d}} \mathrm{A}_{\mathrm{m}} \mathrm{t}_{\mathrm{d}}^{-1}\right)^{-1}+83.3 \mathrm{RT}}$

For secondary fuel cells,

$\rho_{B}=\frac{3661 \eta_{\mathrm{e}} \mu \mathrm{t}_{\mathrm{d}}^{-1}}{3661 \eta_{\mathrm{e}} \mu\left(\mathrm{V}_{\mathrm{d}} \mathrm{I}_{\mathrm{d}} \mathrm{A}_{\mathrm{m}} \mathrm{t}_{\mathrm{d}}^{-1}\right)^{-1}+83.3 \mathrm{RT}+\mathrm{P}_{\mathrm{T}}}$

Substituting equations (5),(22), and (23) into equation (2) and developing expressions for the power density for both primary and secondary fuel cells,

For primary fuel cells,

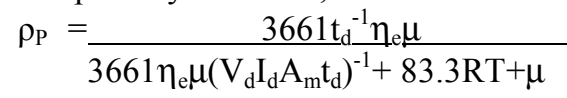

For secondary fuel cells,

$\rho_{P}=\frac{3661 \mathrm{t}_{\mathrm{d}}^{-1} \eta_{\mathrm{e}} \mu}{3661 \eta_{\mathrm{e}} \mu\left(\mathrm{V}_{\mathrm{d}} \mathrm{I}_{\mathrm{d}} \mathrm{A}_{\mathrm{m}} \mathrm{t}_{\mathrm{d}}\right)^{-1}+83.3 \mathrm{RT}+\mathrm{P}_{\mathrm{T}}+\mu}$

The energy density of an energy storage device is also a key metric. The energy density is simply the power density multiplied by the discharge time.

For primary fuel cells,

$\rho_{E}=\frac{3661 \eta_{\mathrm{e}}}{3661 \eta_{\mathrm{e}} \mu\left(\mathrm{V}_{\mathrm{d}} \mathrm{I}_{\mathrm{d}} \mathrm{A}_{\mathrm{m}} \mathrm{t}_{\mathrm{d}}\right)^{-1}+83.3 \mathrm{RT}+\mu}$

For secondary fuel cells,

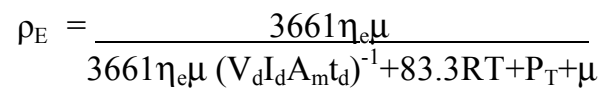

Where

$$
\rho_{\mathrm{E}}=\text { Energy density, watt-hr/kg }
$$

The power density of primary and secondary fuel cells is plotted in Figure 6 using equations (24) and (25). The curves shown for both the primary and secondary fuel cells have horizontal asymptotes. Both curves would also show vertical asymptotes if the curves were extended sufficiently to longer and longer discharge times. The horizontal asymptote in each curve represents a situation where the fuel cell stack is the predominant weight component. This is analogous to a car with a big engine and a small fuel tank. The vertical asymptote in each curve represents a situation where the reactant storage tanks are the predominant components. This is analogous to a car with a small engine and a large fuel tank. Obviously, when much of the mass is dedicated to the power-producing component, the power density is the greatest, whereas when much of the mass is dedicated to the non-power-producing component, the power density is the smallest. Also, it can be seen from Figure 6 that the water storage tank of the secondary fuel cell has relatively little effect on the overall curve.

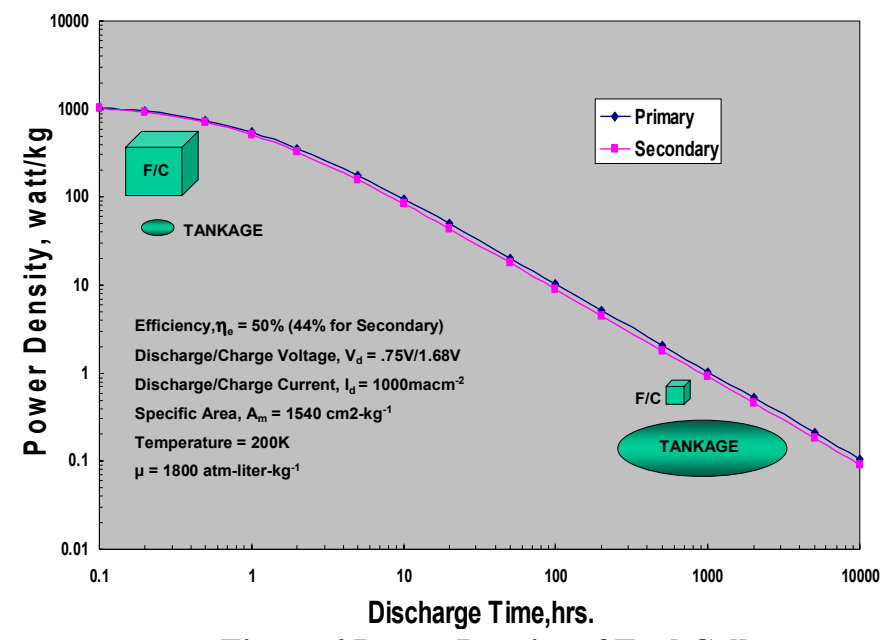

Figure 6 Power Density of Fuel Cells

The energy density for both primary and secondary fuel cells is plotted in Figure 7 using equations (26) and (27). The curves shown for both the primary and secondary fuel cells have horizontal asymptotes. Both curves would also show vertical asymptotes if the curves were extended sufficiently to shorter and shorter discharge times. The horizontal asymptote in each curve represents a situation where the reactant storage tanks are the predominant weight components. This is the car with the big fuel tank and small engine scenario. The vertical asymptote in each curve represents the car with the big engine and small fuel tank scenario. Obviously, when much of the mass is dedicated to the energy-storing component, the energy density is the greatest, whereas when much of the mass is dedicated to the non-energy-storing component, the energy density is the smallest. Also, it can be seen from Figure 7 that the water storage tank of the secondary fuel cell has little effect on the overall energy density results.

A Ragone plot that plots energy density on the horizontal axis and power density on the vertical axis is shown for both primary and secondary fuel cells in Figure 8 . This plot clearly 


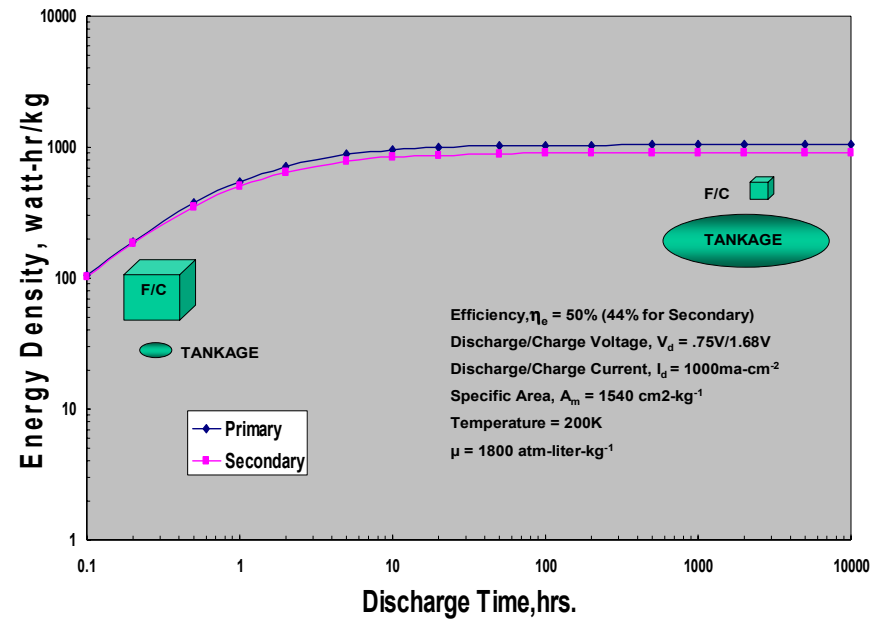

Figure 7 Energy Density of Fuel Cells

shows the effect of discharge time on the energy and power density of fuel cells. As the discharge time gets longer and longer, the fuel cell stack mass has a negligible effect, the reactant storage tanks predominate and the energy density reaches a limit dictated by the performance of the reactant tanks. As the discharge time gets shorter and shorter, the reactant storage tankage mass becomes negligible, the fuel cell stack mass predominates, and the power density reaches a

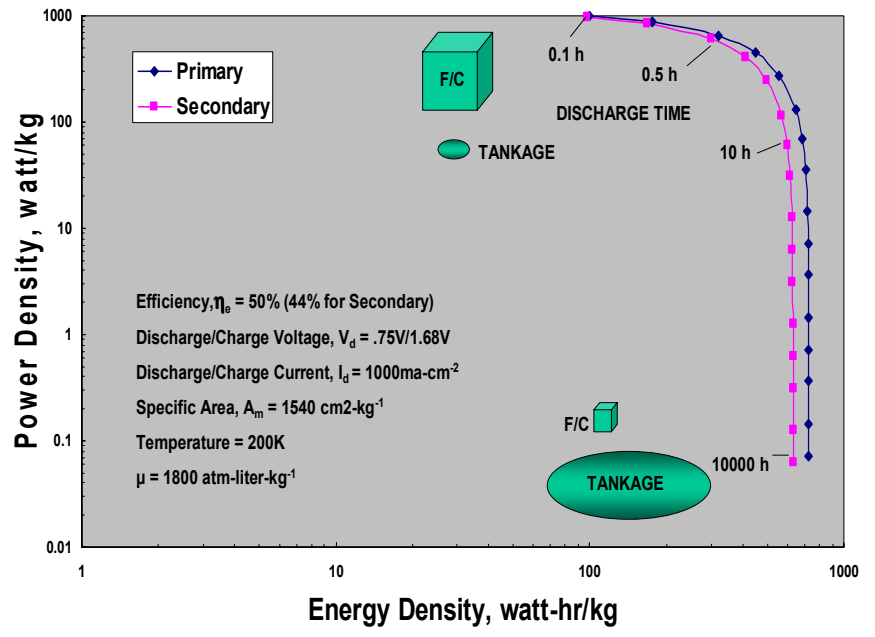

Figure 8 Fuel Cell Energy Density vs. Power Density

limit dictated by the performance of the fuel cell stack. This curve is also instructive to help guide technology developers as to where to emphasize or prioritize development efforts depending on the technology goals.

The plotted results of Figure 8 are superimposed on a battery performance plot [5] shown in Figure 9. This figure clearly shows that fuel cells, both primary and secondary, could potentially fill an energy storage niche not currently filled by battery technology. The applications that could populate this niche will not generally be high power or high energy, but rather they will be generally power dense and energy dense. Fuel cell development by NASA, the government in general,

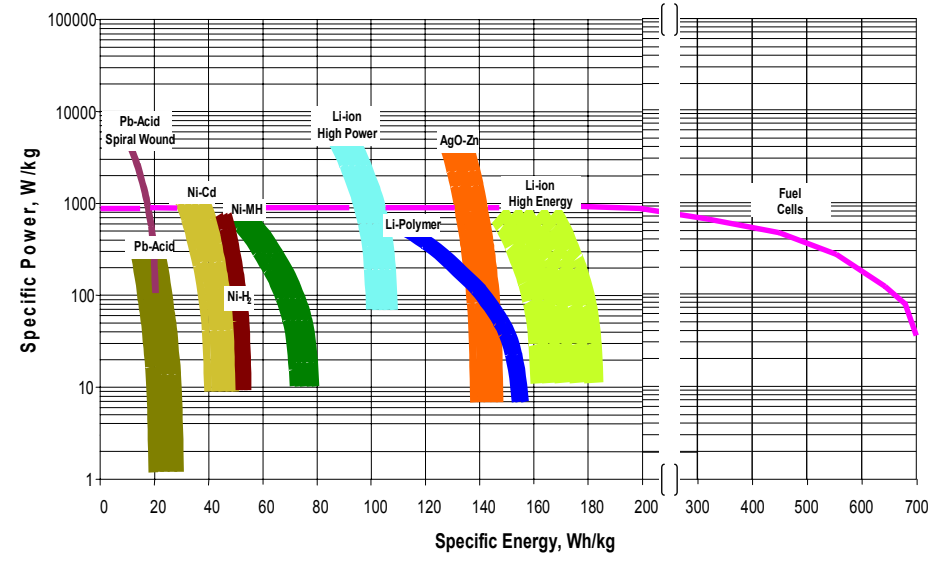

Figure 9 Energy Storage Energy Density vs. Power Density [5]

and commercial interests has focused on the high power or high energy applications, i.e., Space Shuttles and automobiles.

Comparing fuel cells to batteries on a mass basis though is only half of the picture. The other half of the comparison is power density and energy density based on volume. Expressions similar to that developed for mass were developed for volumetric power density and volumetric energy density. The volumetric power density for fuel cells can be expressed as:

$\gamma_{\mathrm{P}}=\frac{\mathrm{P}}{\mathrm{V}_{\mathrm{T}}+\mathrm{V}_{\mathrm{S}}}$

Where

$\gamma_{P}=$ Volumetric power density, watt/liter

$\mathrm{V}_{\mathrm{T}}=$ Tankage volume, liter

$\mathrm{V}_{\mathrm{S}} \quad=$ Fuel cell stack volume, liter

As was the assumption for the mass analysis, the volume of the fuel cell is estimated as the fuel cell stack volume and the reactant storage volume. The reactant itself is of course wholly contained within the volume of the reactant storage volume. Other components, while they do have volume, are not considered for this analysis because their contribution to the overall volume is expected to be minimal, and should not affect the general conclusions of this analysis.

Equation (28) can be rewritten as:

$\gamma_{\mathrm{P}}=\frac{1}{1 / \gamma_{\mathrm{T}}+1 / \gamma_{\mathrm{S}}}$

Where

$\gamma_{\mathrm{T}}=$ Tankage volumetric. power density, watt/liter

$\gamma_{\mathrm{S}}=$ Stack volumetric. power density, watt/liter

The tankage volumetric power density can be expressed as:

$\gamma_{\mathrm{T}}=\frac{\eta_{\mathrm{e}} \xi}{\mathrm{t}_{\mathrm{d}} \mathrm{V}_{\mathrm{T}}}$ 
Using the perfect gas law, equation (30) can be rewritten as:

$\gamma_{\mathrm{T}}=\frac{\eta_{\mathrm{e}} \xi}{1.5 \mathrm{t}_{\mathrm{d}} \mathrm{n}_{\mathrm{w}} \mathrm{RT} / \mathrm{P}_{\mathrm{T}}}$

Equation (14) can be substituted into equation (31),

$\gamma_{\mathrm{T}}=\frac{\eta_{\mathrm{e}} \xi}{1.5 \mathrm{t}_{\mathrm{d}}\left(\mathrm{M}_{\mathrm{T}} / .018\right) \mathrm{RT} / \mathrm{P}_{\mathrm{T}}}$

Replacing the ratio, $\xi / \mathrm{M}_{\mathrm{T}}$ with 3661 watt-hr per $\mathrm{kg}$, and simplifying the expression,

$\gamma_{\mathrm{T}}=\frac{43.93 \eta_{\mathrm{e}} \underline{\mathrm{P}}_{\mathrm{T}}-}{\mathrm{t}_{\mathrm{d}} \mathrm{RT}}$

For secondary fuel cells, the water storage tank volume must be taken into account. This results in equation (34). The derivation has been skipped, but is available from the author.

$\gamma_{\mathrm{T}}=\frac{43.93 \eta_{\mathrm{e}} \underline{\mathrm{P}}_{\mathrm{T}}}{\mathrm{t}_{\mathrm{d}} \mathrm{RT}+.012 \mathrm{P}_{\mathrm{T}}}$

The fuel cell stack volumetric power density can be expressed as:

$\gamma_{\mathrm{S}}=\mathrm{V}_{\mathrm{d}} \mathrm{I}_{\mathrm{d}} \mathrm{A}_{\mathrm{v}}$

Where

$\mathrm{A}_{\mathrm{v}} \quad=$ Active area per unit volume, $\mathrm{m}^{2} /$ liter

Substituting equations (34) and (35) into equation (29) and developing expressions for the volumetric power density for primary and secondary fuel cells yields:

For primary fuel cells,

$\gamma_{\mathrm{P}}=\frac{1}{\left(\mathrm{t}_{\mathrm{d}} \mathrm{RT}\right)\left(43.93 \eta_{\mathrm{e}} \mathrm{P}_{\mathrm{T}}\right)^{-1}+\left(\mathrm{V}_{\mathrm{d}} \mathrm{I}_{\mathrm{d}} \mathrm{A}_{\mathrm{v}}\right)^{-1}}$

For secondary fuel cells,

$\gamma_{\mathrm{P}}=\frac{1}{\left(\mathrm{t}_{\mathrm{d}} \mathrm{RT}+.012 \mathrm{P}_{\mathrm{T}}\right)\left(43.93 \eta_{\mathrm{e}} \mathrm{P}_{\mathrm{T}}\right)^{-1}+\left(\mathrm{V}_{\mathrm{d}} \mathrm{I}_{\mathrm{d}} \mathrm{A}_{\mathrm{v}}\right)^{-1}}$
Figure 10 plots the power density of primary and secondary fuel cells as a function of discharge time. As was the case with the mass analysis, the greatest volumetric power density occurs when the fuel cell stack, the power-producing

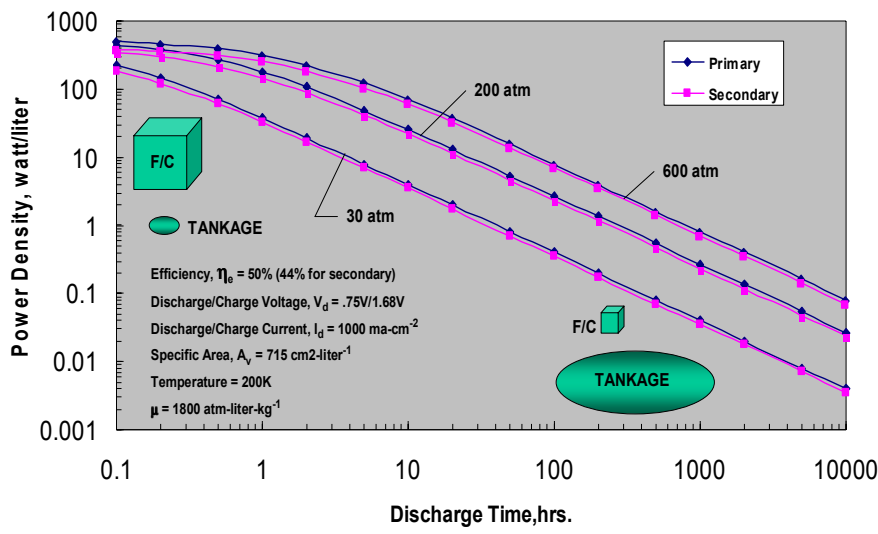

Figure 10 Volumetric Power Density vs. Discharge Time

component, occupies most of the volume. As more and more of the volume is occupied by the reactant storage tankage, the volumetric power density falls off. As the pressure of the reactant storage is increased, the reactant tankage gets proportionately smaller, and the effect on the fuel cell volumetric power density is quite significant. The volume associated with the water storage tank has little effect on the overall volumetric power density.

The volumetric energy density is obtained by multiplying the power density by discharge time.

For primary fuel cells,

$\gamma_{\mathrm{E}}=\frac{1}{\operatorname{RT}\left(43.93 \eta_{\mathrm{e}} \mathrm{P}_{\mathrm{T}}\right)^{-1}+\left(\mathrm{V}_{\mathrm{d}} \mathrm{I}_{\mathrm{d}} \mathrm{A}_{\mathrm{v}} \mathrm{t}_{\mathrm{d}}\right)^{-1}}$

Where

$\gamma_{\mathrm{E}}=$ Vol. energy density, watt-hr/liter

For secondary fuel cells,

$\gamma_{\mathrm{E}}=\frac{1}{\left(\mathrm{RT}+.012 \mathrm{P}_{\mathrm{T}} / \mathrm{t}_{\mathrm{d}}\right)\left(43.93 \eta_{\mathrm{e}} \mathrm{P}_{\mathrm{T}}\right)^{-1}+\left(\mathrm{V}_{\mathrm{d}} \mathrm{I}_{\mathrm{d}} \mathrm{A}_{\mathrm{v}} \mathrm{t}_{\mathrm{d}}\right)^{-1}}$ 
Figure 11 plots the volumetric energy density of primary and secondary fuel cells as a function of discharge time. As was the case with the mass analysis, as the discharge time gets longer and longer, the reactant tankage occupies more and more of the overall volume of the fuel cell. Since the reactant

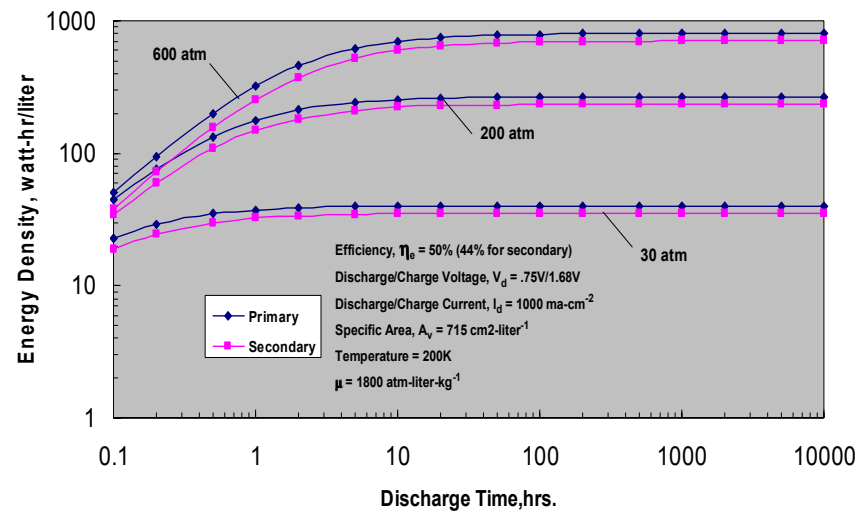

Figure 11 Volumetric Energy Density vs. Discharge Time

storage is the energy storage component, the volumetric energy density continues to increase. As was the case with the volumetric power density, increasing the pressure of the reactant storage proportionately reduces the reactant tankage volume. This significantly affects the overall volumetric energy density. The water storage tank plays an insignificant role in determining the volumetric energy density.

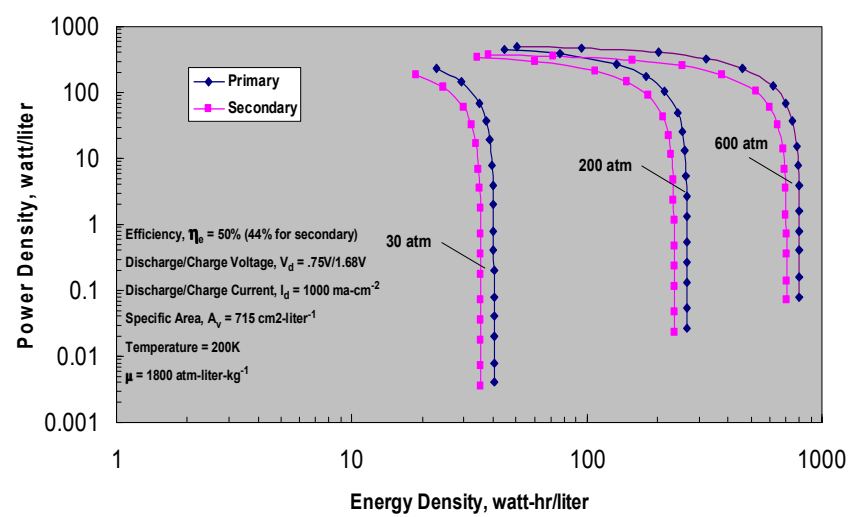

Figure 12 Volumetric Energy Density vs. Power Density

This plot shows the significant effect of reactant pressure on the volumetric energy density. The data shown in Figure 12 is superimposed on battery data shown in Figures 13. These figures show that fuel cells are not competitive with batteries until the reactant storage pressure is 600 atmospheres or greater. At these pressures non-ideal gas behavior should be included in the model in order to refine the analysis, but for the purposes of what was sought in this analysis ideal gas behavior provides a sufficient qualitative answer. The figure also shows that at 600 atmospheres the fuel cell curve is much "flatter" and extends to higher energy

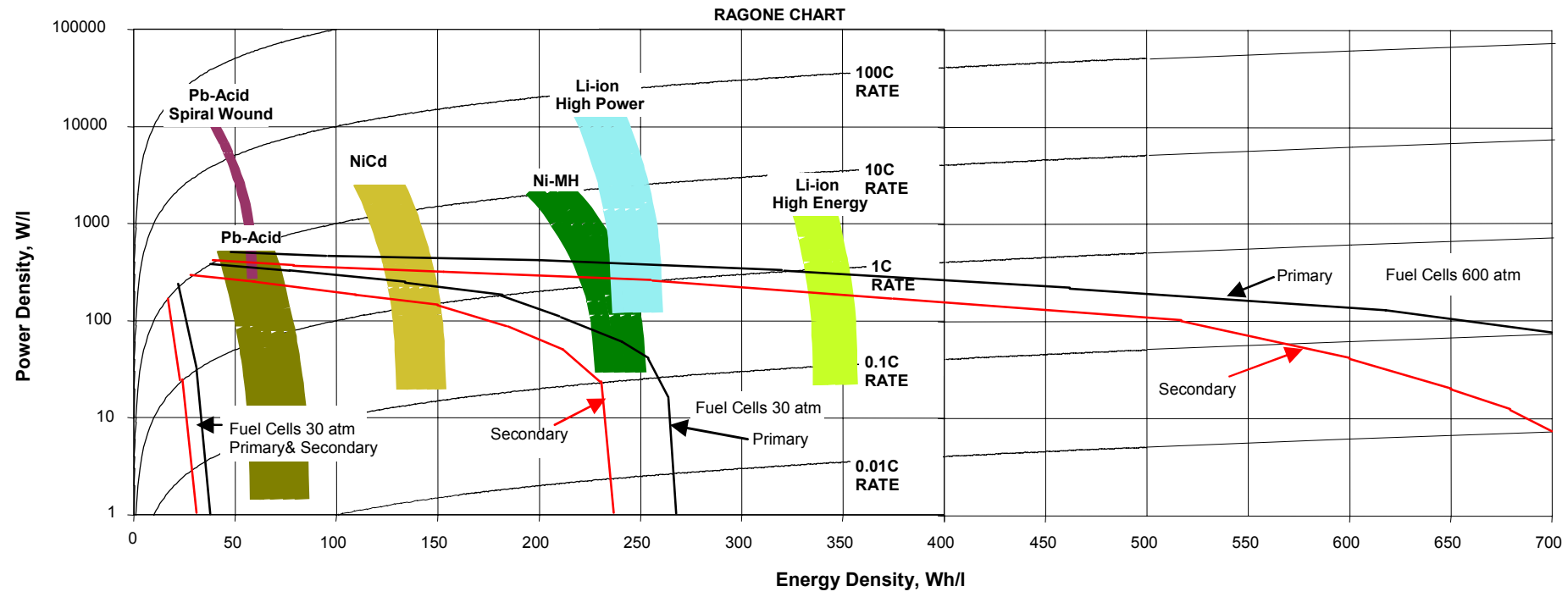

Figure 13 Energy Storage Volumetric Energy Density vs. Power Density [5]

A Ragone plot that plots volumetric energy density on the horizontal axis and volumetric power density on the vertical axis is shown for both primary and secondary fuel cells in Figure 12. densities than current state-of-the-art batteries. This suggests that at sufficiently high pressure ( $>600$ atmospheres) fuel cells could offer volumetric advantages over batteries in some applications. While secondary fuel cell technology is at or 
below the 30-atmosphere level, primary fuel cells could conceivably draw their reactants from high-pressure sources, and have that pressure regulated down to a usable level.

\section{CONCLUSIONS}

The analysis of power density and energy density of fuel cells, and the comparison of that projected performance with current state-of-the-art batteries lead to the following conclusions:

1) Fuel cells can provide "added value" as energy storage devices for space science missions. This added value could take the form of mass savings, volume savings or more power or energy at the same mass and volume.

2) The earliest opportunity for fuel cells to compete with batteries appears to be with primary fuel cells that can draw from high-pressure reactant storage tanks. In the near term, secondary fuel cells appear to offer mass savings, but are not likely to be competitive with batteries on a volume basis.

3) The current fuel cell technology development emphasizes high-power and high-energy applications. A new fuel cell development thrust is needed for applications that are "power dense" and "energy dense". Space science and terrestrial applications that currently use high energy batteries (either primary or secondary) could potentially use these kind of fuel cells. Generally, the power levels and energy levels need to be scaled down by one or more orders of magnitude for these new fuel cell applications.

4) Lightweight, small, high-pressure tanks will be needed ( $>600$ atmospheres) to provide the reactant storage. Similarly, small, lightweight pressure regulators to step down the high gas supply pressure will be needed. Although ancillary mass other than the gas storage tanks and the fuel cell stack was assumed to be relatively small, the fuel cell stacks should be made to operate passively like batteries (i.e. passive reactant management and passive heat removal) to minimize this other ancillary mass.

\section{LIST OF VARIABLES}

$\mathrm{A}_{\mathrm{m}}=$ Fuel cell active area per unit mass $\mathrm{m}^{2} / \mathrm{kg}$

$\mathrm{A}_{\mathrm{v}}=$ Fuel cell active area per unit volume, $\mathrm{m}^{2} /$ liter

$\mathrm{E}=$ Actual Energy Output, watt-hr

$\xi \quad=$ Theoretical Energy Output, watt-hr

$\mathrm{I}_{\mathrm{d}} \quad=$ Fuel cell discharge current density, $\mathrm{A} / \mathrm{m}^{2}$ of active area

$\mathrm{M}_{\mathrm{B}}=$ Mass of the Balance of Plant, $\mathrm{kg}$

$\mathrm{M}_{\mathrm{F}}=$ Mass of Fuel $\left(\mathrm{O}_{2}, \mathrm{H}_{2}\right.$, and $\left.\mathrm{H}_{2} \mathrm{O}\right), \mathrm{kg}$

$\mathrm{M}_{\mathrm{W}}=$ Dry mass of water storage tank, $\mathrm{kg}$

$\mathrm{M}_{\mathrm{S}}=$ Mass of the PEMFC stack, $\mathrm{kg}$

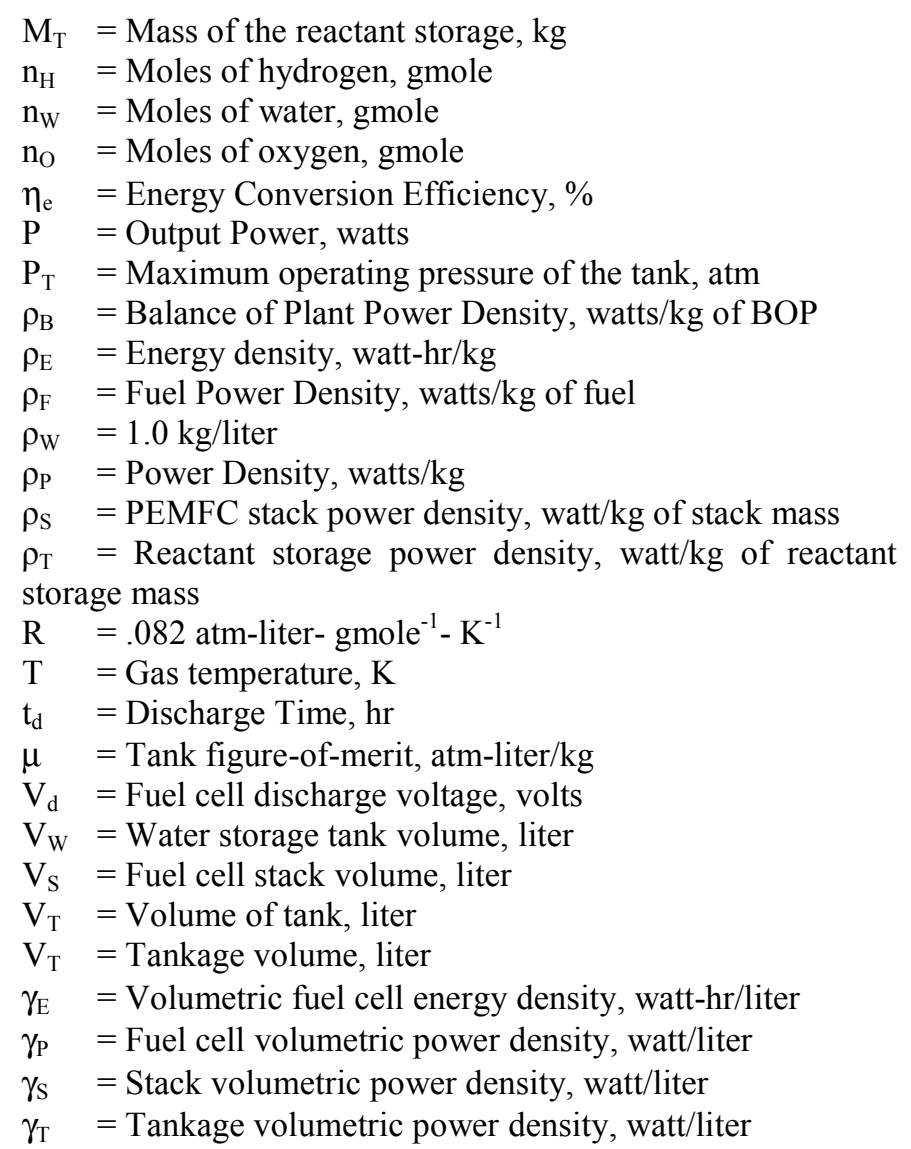

\section{REFERENCES}

[1] NASA website,

http://www-pao.ksc.nasa.gov/kscpao/history/gemini/gemini.htm Barton C. Hacker, James A. Grimwood On the Shoulders of Titans: A History of Project Gemini

[2] National Air and Space Museum website, http://www.nasm.si.edu/galleries/attm/a11.jo.fc.2.html

[3] UTC Fuel Cells website, http://www.utcfuelcells.com/spacedefense/spaceshuttle.shtml

[4] Kenneth A. Burke, "High Energy density Regenerative Fuel Cell Systems for Terrestrial Applications," NASA/TM1999-209429, SAE 00-01-2600, July 1999.

[5] Data presented to the Office of Space Science Energy Storage Review by Robert Staniewicz and Kamen Nechev of SAFT, Goddard Space Flight Center September 26, 2002. 


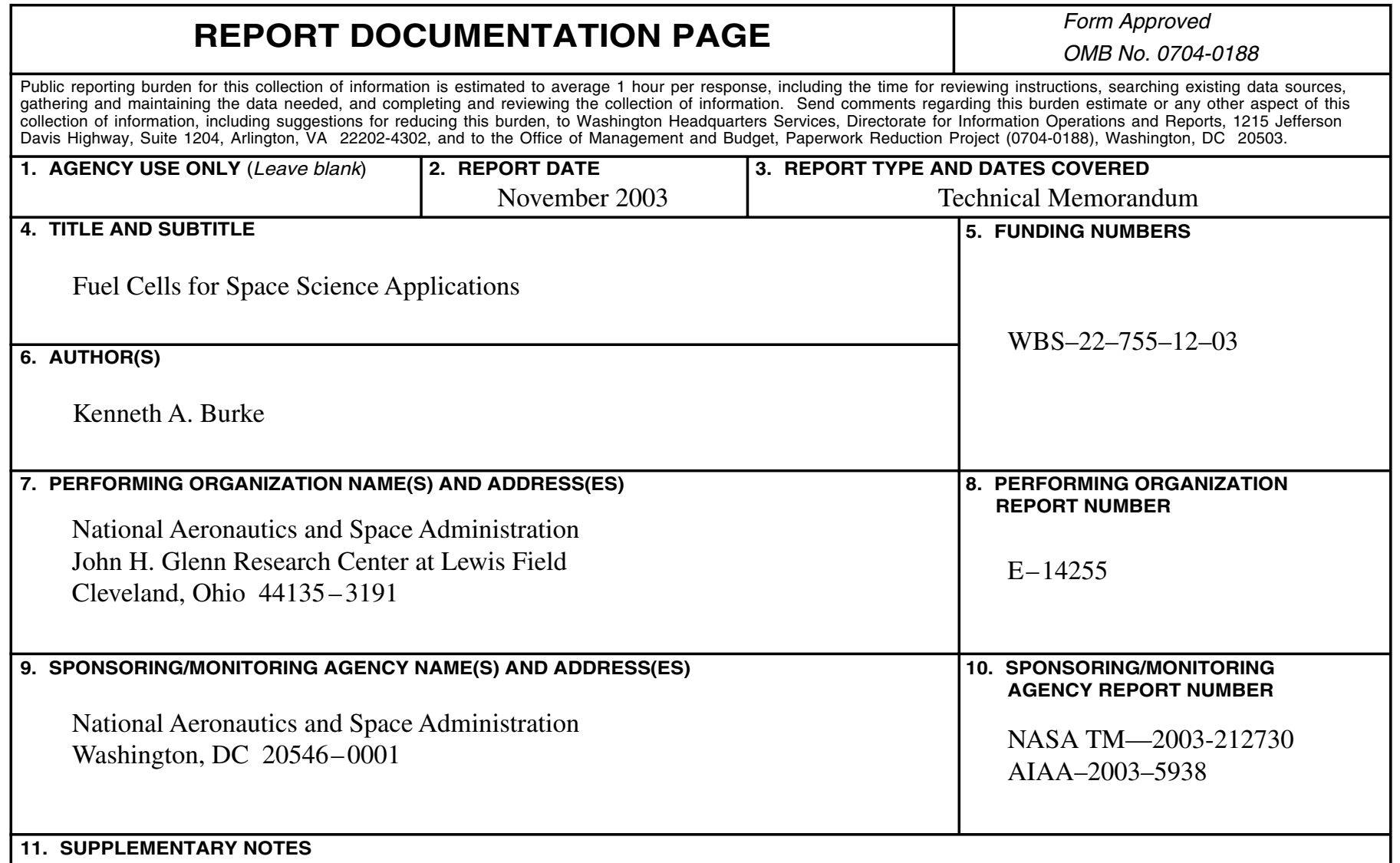

Prepared for the First International Energy Conversion Engineering Conference sponsored by the American Institute of Aeronautics and Astronautics, Portsmouth, Virginia, August 17-21, 2003. Responsible person, Kenneth A. Burke, organization code 5420, 216-433-8308.

12a. DISTRIBUTION/AVAILABILITY STATEMENT 12b. DISTRIBUTION CODE

Unclassified - Unlimited

Subject Category: 44

Distribution: Nonstandard

Available electronically at http://gltrs.grc.nasa.gov

This publication is available from the NASA Center for AeroSpace Information, 301-621-0390.

13. ABSTRACT (Maximum 200 words)

Fuel cell technology has been receiving more attention recently as a possible alternative to the internal combustion engine for our automobile. Improvements in fuel cell designs as well as improvements in lightweight high-pressure gas storage tank technology make fuel cell technology worth a look to see if fuel cells can play a more expanded role in space missions. This study looks at the specific weight density and specific volume density of potential fuel cell systems as an alternative to primary and secondary batteries that have traditionally been used for space missions. This preliminary study indicates that fuel cell systems have the potential for energy densities of $>500 \mathrm{~W}-\mathrm{hr} / \mathrm{kg},>500 \mathrm{~W} / \mathrm{kg}$ and $>400 \mathrm{~W}$-hr/liter, >200 W/liter. This level of performance makes fuel cells attractive as high-power density, high-energy density sources for space science probes, planetary rovers and other payloads. The power requirements for these space missions are, in general, much lower than the power levels where fuel cells have been used in the past. Adaptation of fuel cells for space science missions will require "down-sizing" the fuel cell stack and making the fuel cell operate without significant amounts of ancillary equipment.

\section{SUBJECT TERMS}

Space probes; Storage batteries; Roving vehicles; Primary batteries; Space missions; Fuel cells

\begin{tabular}{|c|c|c|}
\hline $\begin{array}{c}\text { 17. SECURITY CLASSIFICATION } \\
\text { OF REPORT } \\
\text { Unclassified }\end{array}$ & $\begin{array}{c}\text { 18. SECURITY CLASSIFICATION } \\
\text { OF THIS PAGE } \\
\text { Unclassified }\end{array}$ & $\begin{array}{c}\text { 19. SECURITY CLASSIFICATION } \\
\text { OF ABSTRACT } \\
\text { Unclassified }\end{array}$ \\
\hline
\end{tabular}

